\title{
MIROSLAV STEINHAUSZ
}

\author{
(Vukovar, 25. lipanj 1872., \\ Murnau (Seehausen), Bavarska, 19. studenog 1966.)
}

\section{SAŽETAK}

Miroslav (Friedrich) Steinhausz (1872. - 1966.) je svojim stručnim i znanstvenim radom dao veliki doprinos razvoju hrvatskog konjogojstva u prvoj polovici 20. stoljeća. Najveći doprinos dao je razvoju hrvatskog lipicanskog uzgoja kao direktor Državne ergele Stančić, kada je naš lipicanski uzgoj po prvi puta genealoški strukturiran kao temelj kontinuiranog unaprjeđenja uzgoja. Njegove spoznaje i rezultati rada priznati su puno šire, izvan hrvatskih granica, što je i objavljivano u stranoj stručnoj literaturi. Sa stajališta konjogojstva bez sumnje se može reći da je Miroslav Steinhausz najveći velikan u povijesti hrvatskih agrikulturnih znanosti.

Ključne riječi: Miroslav Steinhausz, uzgoj konja, lipicanac, in memoriam

\begin{abstract}
Miroslav (Friedrich) Steinhausz (1872 - 1966) great by contributed to the development of Croatian horse breeding in the first half of the $20^{\text {th }}$ century with his expert and scientific work. His largest contribution was to the development of Croatian Lipizzan breed as director of the State Stud Farm Stančić, when our Lipizzan breed was for the first time genealogicaly structured as a basis for continuos improvement of breeding. His knowledge and results were recognized beyond Croatian borders as published in foreign expert literature. From the horse breeding standpoint, it can be said that Miroslav Steinhaust was the greatest man in the history of Croatian agricultural science
\end{abstract}

Keywords: Miroslav Steinhausz, horse breeding, lipizzan horse, in memoriam 


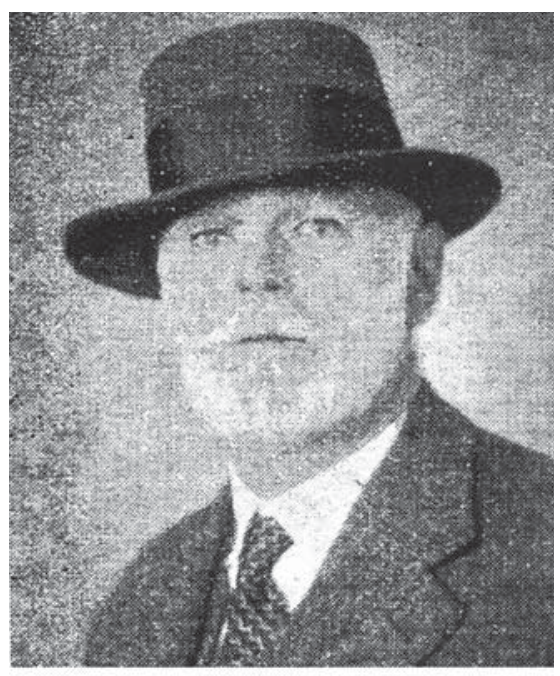

Miroslav Steinhausz

Miroslav Steinhausz rođen je 25. lipnja 1872. godine u Vukovaru, gdje završava osnovnu školu, a petogodišnju gimnaziju pohađa $u$ Oberschützenu $u$ Burgenlandu (Austrija), nakon čega se upisuje na Više gospodarsko učilište $\mathrm{u}$ Križevcima gdje boravi od 1887. do 1890. godine. Od 1890. do 1894. godine bio je gospodarski pristav vlastelinstva grofa Eltza u Vukovaru. Godine 1895. postaje upravitelj, a poslije nadupravitelj Eltzova gospodarstva na Grabovu koje vodi sve do 1920. godine, a od 1904. godine službeno preuzima i njegovu ergelu noniusa na istoj lokaciji.

Od početka radnog vijeka autor je tekstova o konjogojstvu u različitim časopisima. Od 1892. godine surađuje sa časopisima „Gospodar“, „Gospodarska smotra“ u Križevcima, glasilom Hrvatsko-slavonskog gospodarskog društva u Osijeku i glasilom Hrvatskoga gospodarskog društva u Zagrebu te drugim. Također je bio suradnik stranih časopisa kao npr. u glasilu mađarskog zemaljskog društva „Allattenyésztési“ Lapok, u mađarskom časopisu za uzgoj konja i konjički sport „Szent György“. Od njemačkih časopisa, bio je suradnik u „Deutsche Landwirtschaftliche Presse“ koji je bio službeno glasilo Njemačkoga gospodarskog društva u Berlinu te s njemačkim časopisom „Deutsche Landwirtschaftliche Tierzucht“ u Hannoveru i „Sankt Georg“, časopisom za uzgoj konja i konjički sport.

U tekstovima o konjogojstvu od samog početka stručnog rada pokazuje veliko razumijevanje i zanimanje za uzgoj konja. Njegovo najveće zanimanje u početku stručnog rada odnosilo se na proučavanje, osnivanje i razvoj linija pastuha pasmine nonius u mađarskoj ergeli Mezöhegyes, a rezultati istraživanja spomenutog područja objavljeni su u publikaciji pod naslovom „Der Nonius und seine Zucht im Königl. Ung. Staatsgestüt zu Mezöhegyes von 1816 1911." 14. Flugschrift der deutschen Gesellschaft für Züchtungskunde, Berlin.

Do 1920. godine radio je na vlastelinstvu grofa Eltza na Grabovu, a od 1921. do 1923. godine bio je ravnatelj Zemaljskog dobra Božjakovina i upravitelj X. odsjeka pokrajinske uprave za Hrvatsku i Slavoniju, odjeljenja za Narodno gospodarstvo. $\mathrm{U}$ istom razdoblju nije se prestajao zanimati za 
konjogojstvo te je $\mathrm{u}$ isto vrijeme provodio istraživanje i pripremao materijal za svoja dva kapitalna djela. Godine 1923. objavljuje monografiju „Nonius“ u izdanju Hrvatsko-slavonskoga gospodarskog društva u Zagrebu, a 1924. godine i monografiju „Lipicanac“.

Monografija „Nonius“, plod je istraživanja autora ne samo u ergeli Mezöhegyes, nego i u drugim ergelama koje su uzgajale tu pasminu konja. Prema tome, radilo se o izvornoj studiji, a studija se vezala na njegov rad koji je prije objavilo Njemačko poljoprivredno društvo u Berlinu. Uz podatke o osnivanju uzgoja noniusa, autor je sustavno podijelio uzgojni rad na četiri razdoblja. Pojedina su razdoblja važna po određenim uzgojnim zahvatima provođenim u istim razdobljima, tako da su svi zaključci do kojih dolazi rezultat obavljenih istraživanja, što se dalo i zaključiti iz zapažanja drugih konjogojskih stručnjaka i autora publikacija o konjogojstvu. $U$ istim istraživanjima suprotstavio se tvrdnji poznatog konjogojskog stručnjaka grofa Wrangela, koji smatra da je uporaba engleskih punokrvnjaka u uzgoju nonius pasmine proizašla iz potrebe da se spriječe nepovoljne posljedice uzgoja u srodstvu. No, proučavajući matične knjige uspio je dokazati da je upravo uporaba engleskog punokrvnjaka u uzgoju nonius pasmine razlog zbog kojega je vrlo često dolazilo do pojave uzgoja u užem srodstvu.

U stručnom radu uzgoja nonius pasmine konja priklonio se uzgoju srednjeg tipa noniusa, a u tom je smjeru sredio i matično stado noniusa ergele grofa Eltza u Grabovu. Uzgoj nonius pasmine zasnivao je na temeljitoj razradi i povezivanju linija od kojih su se zadržale u uzgoju linije Nonius XXIX., Nonius XXXI. i Nonius XXXVI. Temeljito poznavanje uzgojne izgradnje noniusa pomoglo mu je da upravo zbog dobrog poznavanja genealogije nonius pasmine u Hrvatskoj pronađe 1915. godine stanišnog pastuha 302 Nonius, kao jedinog tada živog predstavnika linije Nonius III. Na toga pastuha upozorio je upravu ergele Mezöhegyes koja ga je poslije dopremila u ergelu i koristila u rasplodu te je na taj način sačuvana ta linija pastuha. Godine 1910. počeo je istraživati podrijetlo rodova nonius kobila koje je htio, kao i kod linija pastuha razvrstati i sistematizirati, no u tome ga je spriječio Prvi svjetski rat. U proučavanju nonius pasmine, naročito je veliki interes imao u proučavanju udjela drugih pasmina konja u uzgojnoj izgradnji nonius pasmine. Posebno se zanimao za proučavanje primjene uzgoja u srodstvu u izgradnji te pasmine konja te je ustvrdio da je pasmina kontinuirano izgrađivana kroz uzgoj u daljnjem srodstvu, a u nekim slučajevima se svjesno primjenjivao i uzgoj u najužem srodstvu. 
Svojim proučavanjem i saznanjima o izgradnji i uzgoju nonius pasmine konja i opisivanjem povijesti i rada ergela u kojima se uzgajala ta pasmina, posebice ergele vlastelinstva grofa Eltza u Vukovaru i Državne ergele Karađorđevo, dao je osnovne smjernice za uzgojni rad ne samo u tim nego i drugim ergelama nonius pasmine. Unatoč tomu što se na području „nove“ Jugoslavije potpuno zapustio i nestao uzgoj noniusa, proučavanje Miroslava Steinhausza i danas ima veliko značenje u onim zemljama u kojima se i danas uzgaja ta pasmina. Dijelom je to zbog njegovih stručnih i znanstvenih spoznaja, a dijelom i radi toga što se u drugim zemljama u rodoslovljima današnjih nonius grla nalaze preci grla koji su uzgojeni upravo pod Steinhauszovim stručnim nadzorom i smjernicama.

Druga znatno veća i značajnija studija Miroslava Steinhauzsa, je proučavanje lipicanske pasmine konja, a spoznaje iz te studije objavljene su 1924. godine u monografskoj knjizi naslova „Lipicanac“. U knjizi su opisani nastanak i uzgojna izgradnja lipicanske pasmine, a detaljno su opisani nastanak i genealogija linija pastuha i rodova kobila. Iscrpno je prikazana uzgojna izgradnja lipicanske pasmine u ergeli Lipica i uzgoj lipicanaca u drugim ergelama prve Jugoslavije i šire. Opširno opisuje stare lipicanske ergele obitelji grofova Jankovića u Suhopolju/Terezovcu i Cabuni. Iako nije imao priliku izravno proučavati ergelske matične knjige $u$ tim ergelama, uzgojnu izgradnju tih ergela proučavao je iz rodovnica rasplodnih lipicanskih pastuha koji su nabavljani od grofova Jankovića od 1870. do 1918. godine za zemaljski uzgoj te prema rodovnicama lipicanskih kobila koje su nabavljene 1919. godine za početno matično stado Državne ergele Stančić. Ergela grofa Jankovića osnovana je 1800. godine ponajviše s konjima španjolskog i napuljskog podrijetla, a sve do 1860. godine u rasplodu su korišteni uglavnom pastusi vlastitog uzgoja. Od 1860. godine u uzgoj su uvedeni lipicanski pastusi iz ergele Lipica, a tom prigodom dopremljeno je i nekoliko lipicanskih kobila. Kroz proučavanje genealoških podatka Steinhausz je ustvrdio da je od starih španjolskih linija sačuvana samo jedna linija kroz hrvatsku lipicansku liniju pastuha Tulipan. Nadalje, ustvrdio je da uzgojni rad ergele grofa Jankovića karakterizira s jedne strane pretežita uporaba pastuha vlastitog uzgoja, a s druge strane sustavna uporaba lipicanskih pastuha iz drugih uzgoja koji su u podrijetlu imali malo manji udio arapske krvi.

Obje knjige, i „Nonius“ i „Lipicanac“, bile su važne za kasniji rad na unapređenju ukupnog konjogojstva, jer je njima vrlo precizno definiran uzgojni plan, a ujedno su iscrpno opisane sve mjere na poboljšanju uzgoja u ergelama i u zemaljskom uzgoju konja. 
Godine 1924. Miroslav Steinhausz postaje direktor Državne ergele Stančić i Državnog pastuhskog staništa u Kutjevu, a u vezi s dužnosti direktora upravljao je i cijelim zemaljskim uzgojem konja u Hrvatskoj. Nakon preuzimanja dužnosti direktora državne ergele, potpuno se posvetio vođenju ergele i zemaljskog konjogojstva te mu je u istom razdoblju i stručni literarni rad usko vezan za tu tematiku.

U tom razdoblju njegovi najvažniji radovi su:

1. Das „Turc-Main-Atty“ Blut in der Landespferdezucht von Ungarn, Rumänien und Südslawien. Zeitschr. f. Tierzüchtung u.

Züchtungsbiologyie, Bd. 18, Berlin, 1930.

2. Rodovnica i rodoslovlje - Sastavljanje i upotreba kod izbora i parenja rasplodnjaka. Poljoprivredna knjižnica, Zagreb, 1931.

3. Zemaljski uzgoj konja s posebnim osvrtom na Vojvodinu.

Gospodarski list, br. 11 i 12, Zagreb, 1933.

4. Temelji uzgoja konja. Napredak sela. Zagreb, 1933.

5. Uzgoj konja u Međimurju. Poljoprivredna knjižnica, Zagreb, 1934.

6. Uzgoj konja u Savskoj banovini. Ibidem, Zagreb, 1935.

7. Jugoslavenski nonius. Ibidem, Zagreb, 1935.

8. Uzgoj konja. Ibidem, Zagreb, 1939.

U vrijeme dok su objavljivane navedene publikacije, iako su prilično različitih tematika, imale su već onda veliku važnost, jer su obrađivale tadašnje vrlo važne probleme u uzgoju konja. Za ondašnje uvjete vrlo veliku vrijednost imali su radovi koji su upućivali na smjernice unapređenja zemaljskog konjogojstva. Vrlo važno je istaknuti 1925. godine objavljen „Pravilnik“ za rad na pastuhskom staništu i na pripusnim stanicama Državne ergele Stančić, koji je uvelike pomogao stvaranje stabilne i funkcionalne organizacije na unapređenju zemaljskog uzgoja konja. O velikom doprinosu Steinhauszova znanja i rada ne samo u ergelskom radu, nego i unapređenju zemaljskog konjogojstva svjedoče brojni podaci o osnivanju velikog broja konjogojskih udruga i pripusnih stanica za vrijeme dok je bio direktor Državne ergele Stančić i na čelu hrvatskog zemaljskog uzgoja konja. 
Zbog velikih rezultata u stručnom, praktičnom i znanstvenom radu, 11 . rujna 1933. godine u hotelu „Esplanade“ u Zagrebu, kolege agronomi Poljoprivrednog odjeljenja kraljevske Banske uprave Savske banovine pripremili su Miroslavu Steinhauszu veliko primanje. Tom prigodom odali su mu priznanje na velikom doprinosu u unapređenju ergelskog i zemaljskog uzgoja konja te mu predali umjetnički izrađenu plaketu na kojoj je lik lipicanskog pepinjernog pastuha Državne ergele Stančić 372 Favory V-1 (Rad.1910.), a izradio ju je kipar Ivo Kerdić. Na plaketi je ispisana posveta: „Gospodinu Miroslavu Steinhauszu ravnatelju Državne ergele Stančić za njegov odličan rad na konjogojstvu posvećuju stručni drugovi. U Zagrebu, 9. rujna 1933.“ (slika 1). Priznanju se pridružilo uredništvo časopisa Poljoprivredni glasnik koje mu je iznijelo javnu zahvalu u članku časopisa pod naslovom: „Priznanje rada Miroslava Steinhausza“, objavljenom u listopadu 1933. godine.

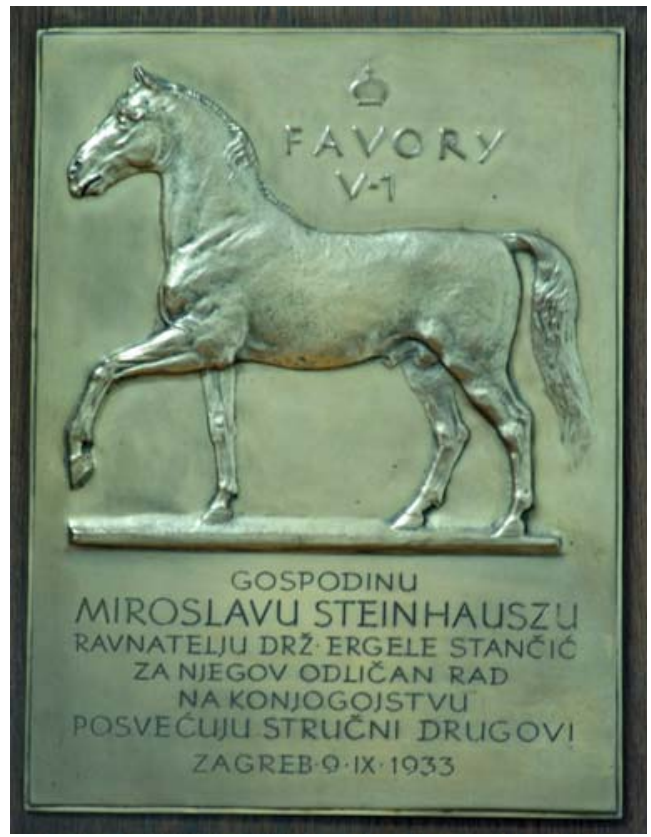

Slika 1. Plaketa s posvetom dodijeljena ing. Miroslavu Steinhauszu 1933. godine za veliki doprinos unapređenju ergelskog i zemaljskog uzgoja konja (foto: M. Čačić)

Picture 1 Plaque dedicated to Miroslav Steinhausz in 1933., for the great contribution to improvement of stud farm and private horse breeding (photo: M. Čačić) 
U knjizi „Jugoslavenski nonius“ prikazuje značajke domaćeg uzgoja u odnosu na stanje uzgoja noniusa u Mađarskoj. Stručni rad tog razdoblja završava knjigom naslova „Uzgoj konja“, koja je u to vrijeme bila prva modernija publikacija o uzgoju konja, a koja je ujedno bila rezultat njegova 50 - godišnjeg rada u konjogojstvu i upravo je na 50. obljetnicu svog rada 1940. godine umirovljen.

No, i nakon umirovljenja Miroslav Steinhausz nastavlja se baviti stručnim publikacijskim radom te objavljuje tri vrlo važne knjige: Linije pastuha i rodovi kobila hrvatskog noniusa, Zagreb, 1941; Linije pastuha i rodovi kobila hrvatskog lipicanca, Zagreb, 1943; Uzgoj hladnokrvnog konja, Zagreb, 1944.

U knjigama o lipicanskoj $i$ nonius pasmini u svojim konačnim razmatranjima i zaključcima prikazuje postignute uzgojne rezultate, ali i smjernice budućeg uzgojno-selekcijskog rada u uzgojima tih pasmina. No, tijekom Drugog svjetskog rata znatno su uništeni mnogi uzgoji konja, a uz to je politika u Hrvatskoj dovela do ukidanja uzgoja nonius pasmine konja. I lipicanski uzgoji bili su vrlo oslabljeni i raspršeni, tako da je knjiga o linijama pastuha i rodovima kobila hrvatskog lipicanca uvelike poslužila nakon Drugog svjetskog rata u sređivanju hrvatskog lipicanskog uzgoja. Time se može reći da je ista knjiga ispunila svoju svrhu te da je to velika poslijeratna zasluga gosp. Miroslava Steinhausza na unapređenju našeg lipicanskog uzgoja. Njegova je knjiga također postala važno gradivo konjogojskih stručnjaka izvan hrvatskih granica koji su stručnim radom djelovali u uzgoju lipicanske pasmine.

I danas se još može reći da su neka njegova razmišljanja aktualna i primjenjiva. Čak i onda je u svojim radovima izjavio, kada se govori o osnovama rada na uzgoju lipicanaca: “...da je uzgojni rad bio te da ostaje i nadalje rad za budućnost...".

Uzgojni rad i poslije uzgojnu izgradnju lipicanca i noniusa zasnivao je na pojedinim linijama i uvijek je nastojao da se u linijama koje je odabrao održavaju pojedini ogranci, koji su nastali od pastuha znatno boljih od prosjeka te je smatrao da te ogranke linija treba ne samo održavati nego izgrađivati za budućnost. Takvim pristupom postigao je vrlo veliko grananje linija pastuha, a budući da su pastusi osnivači ogranaka bili nadprosječni pastusi, u istim ograncima osiguravao je uzgojni potencijal za buduće generacije. Proučavanjem uzgojne izgradnje došao je do spoznaje da su pojedini istaknuti pastusi imali odlučujući utjecaj na uzgoj u određenom razdoblju. Držeći se toga načela, pri uzgoju lipicanske pasmine kao direktor Državne ergele Stančić vrlo izdašno je u rasplodu koristio pepinjernog pastuha 372 Favory V-1 (Rad.1910.), a u uzgoju nonius pasmine pastuhe 270 MB Nonius XLII-13 i njegova sina E Nonius XI., te pastuha 
E Nonius X. Ovaj pristup zaista je donio cijelom jednom uzgojnom razdoblju temelje za budući uzgojni rad u istim pasminama. Takvi pastusi predstavljali su ono što se u stočarskoj literaturi smatralo „individualnim potencijalom“.

Svojim radom Steinhausz je doveo uzgojni rad prema linijama pastuha i rodovima kobila do vrhunca, a temelj za takav rad zasigurno je dobro poznavanje genske i uzgojne vrijednosti rasplodnog materijala. Smatra se da u nekadašnjoj stočarskoj stručnoj literaturi koja je objavljena u Hrvatskoj, ima najmanje radova o uzgojnoj problematici. Budući da je tu prazninu Miroslav Steinhausz uvelike popunio svojim studijama i publikacijama, iako se bavio konjogojstvom, ta je literatura bila vrlo često temelj istraživanja za druge vrste i pasmine domaćih životinja. Prema tome, rad Miroslava Steinhausza ima veliko opće značenje koje se u povijesti našeg stočarstva nikako ne može zaobići.

Miroslav Steinhausz umro je u 94-toj godini, 19. studenog 1966. godine u mjestu Murnau (Seehausen) u Bavarskoj (Njemačka), gdje je živio nakon Drugog svjetskog rata.

\section{POTVRDA STRUČNOG RADA MIROSLAVA STEINHAUSZA}

Kao glavne potvrde stručnog rada i doprinosa Miroslava Steinhauza hrvatskom konjogojstvu mogu se kao najznačajniji istaknuti ostvareni rezultati konja ergele Stančić i pastuharne Kutjevo kao njene ispostave na daljinskom jahanju 1926., I. zemaljskoj izložbi konja u Beogradu 1937. te rezultati sudjelovanja na 14. Međunarodnom jahaćem, skakačem i vozarskom turniru u Aachenu 1938. godine.

Daljinsko jahanje 1926.

Ministarstvo poljoprivrede i voda u suradnji s Dunavskim kolom jahača „Knez Mihajlo“, potaknulo je organizaciju daljinskog jahanja 1926. godine za konje i jahače državnih i privatnih ergela, kako bi se utvrdilo koje su pasmine konji najpogodniji za daljinsko i terensko jahanje, ali i da se utvrdi znanje i vještina jahača da zadanu udaljenost prijeđu s konjem te da pri tome veliku pozornost posvete štednji konja. Osim toga važno je bilo utvrditi radnu i uporabnu vrijednost konja koji su uzgajani u državnim i privatnim ergelama. U natjecanju su sudjelovale: Državna ergela Ljubičevo (Srbija) s dva pastuha engleske polukrvne pasmine; Državna ergela Goražde (Bosna i Hercegovina) s pet pastuha arapske polukrvne pasmine, Državna ergela Stančić (Hrvatska) s četiri kobile lipicanske pasmine i Ergela vlastelinstva kneza Odescalchi (Srijem) s četiri arapska punokrvna pastuha. 
Natjecanje $\mathrm{u}$ daljinskom jahanju na udaljenost od $255 \mathrm{~km}$, organizirano je $\mathrm{u}$ četiri etape, a polazak svih natjecatelja određen je 18. rujna 1926. godine u 17.30 sati. Sve etape završavale su 19. rujna 1926. godine u Beogradu na trkalištu Dunavskog kola jahača kod Careve Ćuprije.

U trening je stavljeno pet kobila matičnog stada Državne ergele Stančić vlastitog uzgoja (6 Bašica I, St.1921; 29 Nana I, St.1921; 66 Morava I, St.1921; 71 Cimbal I, St.1921; 72 Gaetana I, St.1921.), te dva pastuha iz Državnog pastuhskog staništa Kutjevo (464 Pluto Balz, E.1922; 216 Kadat OX, Ilok.1917).

Trening konja počeo je 19. srpnja 1926. godine i provodio se na pastuhskom staništu u Kutjevu, a voditelj treninga bio je upravitelj pastuhskog staništa Milivoj Sekulić. Velika važnost tijekom treninga dana je prelaženju što većih udaljenosti korakom i to na tvrdoj kamenoj cesti. Budući da su kobile tek došle iz ergele i nisu bile ujahane, trening se provodio dijelom pod sedlom i dijelom $u$ zaprezi. Takav trening pokazao se vrlo dobrim, jer se time znatno umanjila mogućnost ozljeda nogu. Dnevna udaljenost, koju su konji prelazili, povećavala se postupno, pazeći da su konji prije treninga „,svježi“ i odmorni.

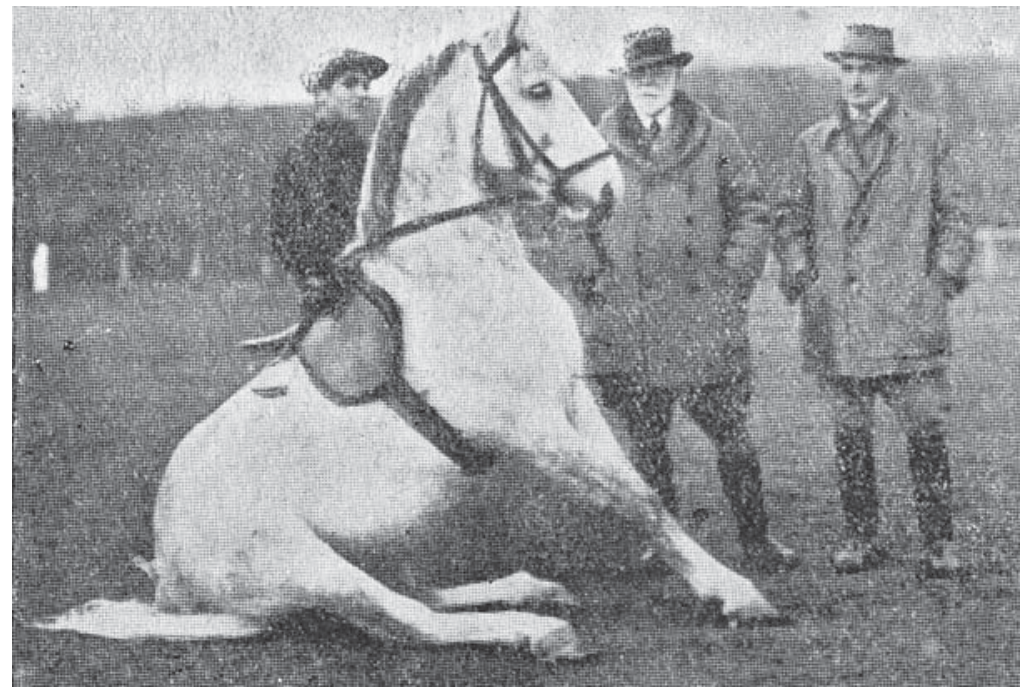

Foto 1. Lipicanski pastuh pastuhskog staništa u Kutjevu s jahačem polaznikom Škole lakih jahača u Kutjevu, direktor Državne ergele Stančić i Državnog pastuhskog staništa

Kutjevo ing. Miroslav Steinhausz i upravitelj Državnog pastuhskog staništa Kutjevo gosp. Milivoj Sekulić. (arhiva autora)

Foto 1 Lipizzan stallion from stallion station in Kutjevo with equestrian, attendant of School of light equestrians in Kutjevo, director of Stade Stud Farm Stančić, and State Stallion Station Kutjevo, Mr. Milivoj Sekulić (author's archive) 
Daljinsko jahanje na udaljenost od 255 km održano je 18. i 19. rujna 1926. godine, a nastupilo je 15 jahača. Početak natjecanja za grla Državne ergele Stančić 18. rujna 1926. godine (subota) u 17.30 sati bio je iz mjesta Majara, a od početno sedam treniranih startala su četiri grla i to lipicanske kobile: 6 Bašica I, St.1921; 29 Nana I, St.1921; 66 Morava I, St.1921; 72 Gaetana I, St.1921). Preostala tri grla koja su bila odabrana za natjecanje i uvedena u trening, nisu nastupila na natjecanju zbog ozljede nogu tijekom treninga.

Prve dvije kobile, 29 Nana I (St.1921.) i 66 Morava I (St.1921.), stigle su zajedno u 19.50 sati u Beograd na trkalište kod Careve Ćuprije, a put od $255,6 \mathrm{~km}$ prešle su za 26.20 sati, ili prosječnom brzinom od $9,7 \mathrm{~km} / \mathrm{sat}$ i osvojile drugo i treće mjesto. Za manje od jednoga sata poslije, točnije u 20.40 sati također zajedno na trkalište stižu i kobile 72 Gaetana I (St.1921.) i 6 Bašica I (St.1921.) i, te osvajaju četvrto i peto mjesto.

Sve četiri kobile pri dolasku na trkalište nisu izgledale jako premorene, što je potvrdilo ispravnost treninga. Jednim dijelom zasluge za dobre rezultate kobila u natjecanju treba pripisati dobrom uzgojnom i selekcijskom radu Miroslava Steinhausza, a drugim upravitelja Milivoja Sekulića koji je trening vodio stručno i razumno (foto 1 ). Osim toga, tijekom treninga i jahači su uvježbavani za daljinsko jahanje, odnosno pažljivom i stručnom jahanju i postupanju s konjima.

I. zemaljska izložba konja u Beogradu 1937.

Ministarstvo poljoprivrede organiziralo je 12. i 13. rujna 1937. godine u Beogradu "I. zemaljsku izložbu konja“. Na toj izložbi Državna ergela Stančić sudjelovala je s 21 lipicanskim pastuhom od kojih je 15 pastuha vlastitog uzgoja. Pastusi su na izložbi nastupili u priredbi pod sedlom i u zapregama te dobili najbolje ocjene od stručnih komisija (foto 2). No pored ostvarenih dobrih rezultata na izložbi, vrlo značajan događaj je da su na izložbi nazočili i vrlo dobro ocijenili konje ergele Stančić njemački konjogojski stručnjak Gustav Rau iz Berlina i zapovjednik mađarske državne ergele Bábolna Pettko Szanrfner. 


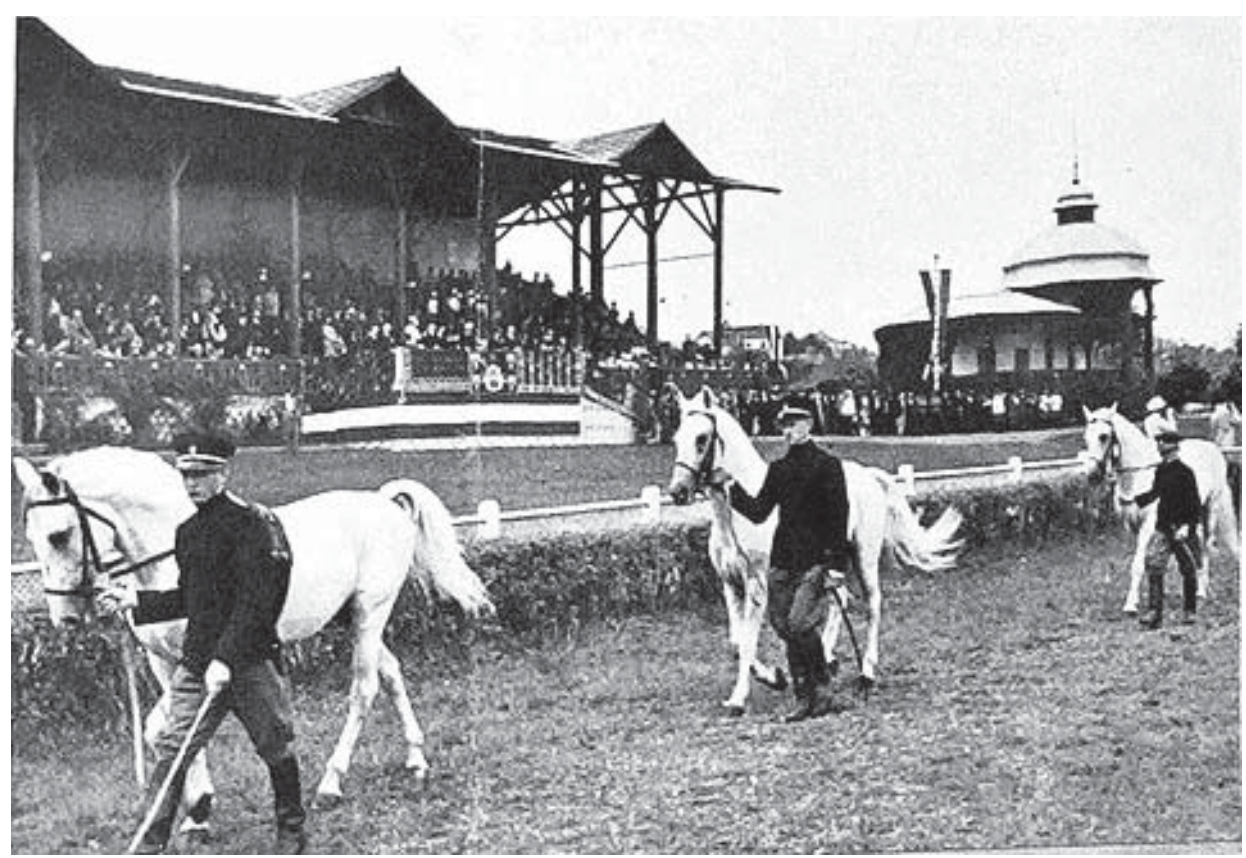

Foto 2. Kolekcija lipicanskih pastuha pastuhskog staništa и Kutjevu na I. zemaljskoj izložbi konja u Beogradu 1937. godine (arhiv autora)

Foto 2 Colection of Lipizzan stallions of Stallion Station in Kutjevo on the $1^{\text {st }}$ State show of horses in Belgrade, 1937. (author's archive)

14. međunarodni jahaći, skakači i vozarski turnir u Aachenu 1938.

Rješenjem Ministarstva poljoprivrede (broj 27287/III od 6. travnja 1938. godine), pastuhsko stanište Kutjevo sudjelovalo je na 14. međunarodnom jahaćem, skakačem i vozarskom turniru u Aachenu (Njemačka) od 12. do 21. kolovoza 1938. godine. Na turniru je sudjelovalo 17 država s 561 konjem i oko 30.000 prijava. Sudjelovanje je ostvareno na temelju molbe predsjedništva organizatora turnira, a na prijedlog Gustava Raua. Troškove je snosila uprava turnira (prijevoz, smještaj, boravak i ostalo).

Vođa ekipe Državnog pastuhskog staništa Kutjevo bio je upravitelj pastuhskog staništa Milivoj Sekulić, njegov pomoćnik bio je Teodor Bartolović, koji je ujedno bio i vršitelj dužnosti upravitelja ergelskog odjeljenja u Lipiku, a kao nadstojnik i jahač sudjelovao je Mijo Tkalčec (foto 3). Na natjecanju u više 
disciplina sveukupno je nastupilo 20 lipicanskih pastuha. Kutjevačka ekipa je tijekom turnira nastupala svaki dan i to u neparne dane pod sedlom u kvadrili sa 16 jahača i konja, a u neparne sa zapregama i to s peteropregom, četveropregom i dvopregom, a nastupili su i u dvopregu slavonskih kola sa starim graničarskim hamom i posadom u slavonskoj nošnji brodske regimente.

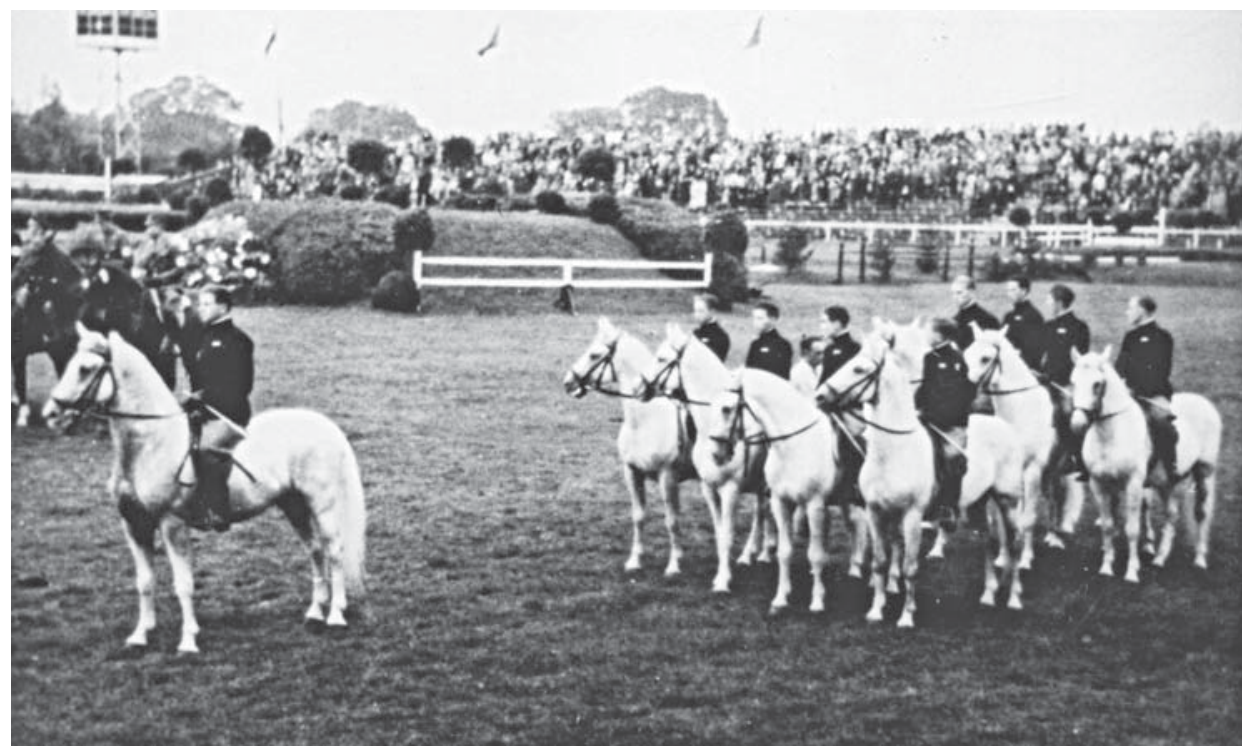

Foto 3. Dio kutjevačke ekipe tijekom otvorenja turnira u Aachenu 1938. (arhiv autora)

Foto 3 Some of Kutjevo team during the opening of tournament in Aachen, 1938 (author's archive)

$\mathrm{Na}$ aachenskom turniru je ekipa kutjevačkog pastuhskog staništa postigla vrlo dobre uspjehe. Prema izjavama organizatora i najmjerodavnijih stručnjaka, ni na jednom dosadašnjem turniru organiziranom u Aachenu nije se pojavila takva kolekcija konja izjednačena prema ljepoti i jednoličnosti tjelesne vanjštine. Najveća atrakcija bila je kutjevačka kvadrila i nastupi u zapregama kojima je upravljao upravitelj pastuhskog staništa Milivoj Sekulić (foto 4). 


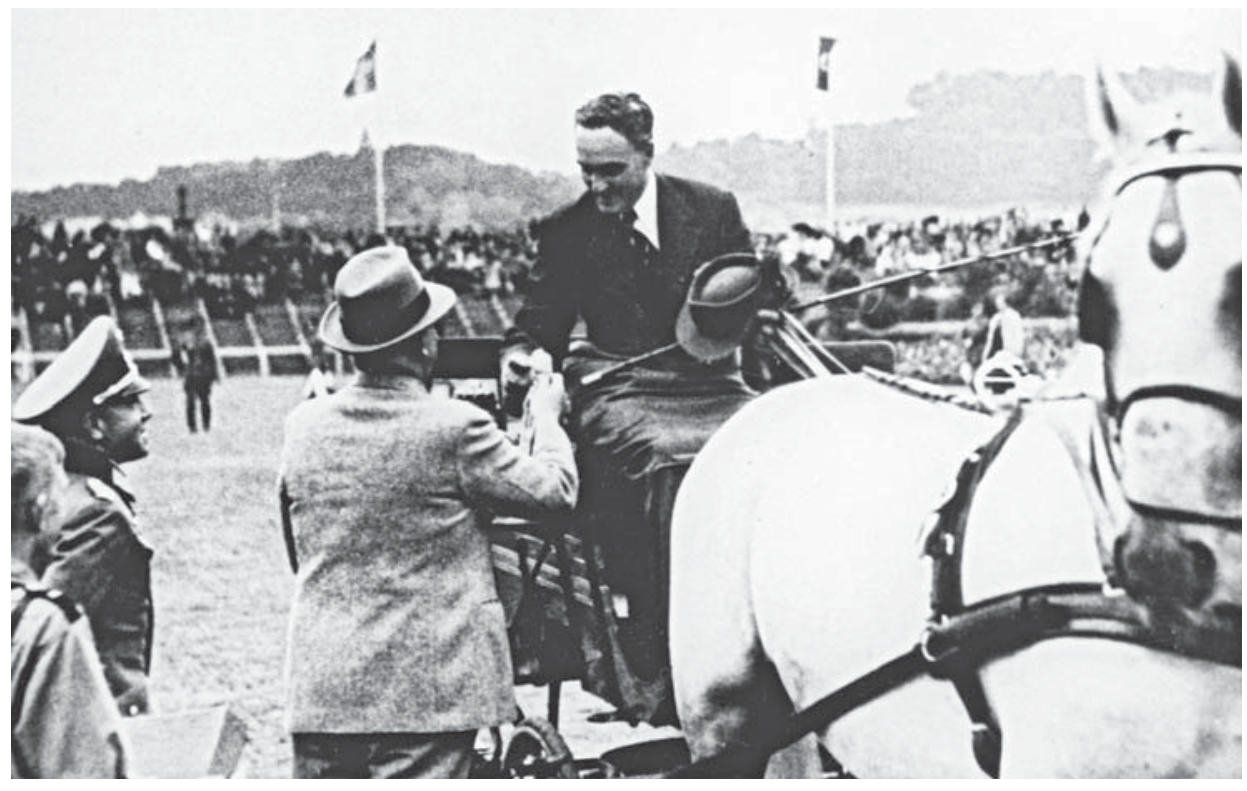

Foto 4. Upravitelj pastuhskog staništa Milivoj Sekulić preuzima osvojenu I. nagradu za nastup kutjevačkog peteroprega (arhiv autora)

Foto 4 Director of Stallion Station receiving the I. prize won by Kutjevo five-in-hand (author's archive)

Nastup kutjevačkih lipicanskih pastuha, na 14. međunarodnom jahaćem, skakačem i vozarskom turniru u Aachenu 1938. godine, nedvojbeno je bio vrlo zapažen i izvrsna atrakcija, a publika je bila vrlo oduševljena. Nakon povratka, upravitelj Milivoj Sekulić kao vođa kutjevačke ekipe podnio je Ministarstvu poljoprivrede izvještaj o nastupu na turniru (broj 6210 od 1. rujna 1938. godine i 6366 od 12. rujna 1938. godine).

Nakon toga, Ministarstvo poljoprivrede i voda pozvalo je Gustava Raua, jednog od najpoznatijih svjetskih konjogojskih stručnjaka, da obavi pregled svih državnih i privatnih ergela te dijela zemaljskog uzgoja stare Jugoslavije. Gustav Rau je došao u Zagreb 12. rujna 1938. godine. Već sutradan, 13. rujna 1938. uputio se željeznicom u Kutjevo, a 14. rujna 1938. pregledao je sva grla na pastuhskom staništu. Nakon pregleda, naš uzgoj ocijenio je najboljim svjetskim uzgojem, a o pregledu je podnio izvještaj Ministarstvu poljoprivrede. Taj je izvještaj objavljen i u časopisu Deutche St. Georg Spatzeitung, broj 3. iz 1939. godine. 


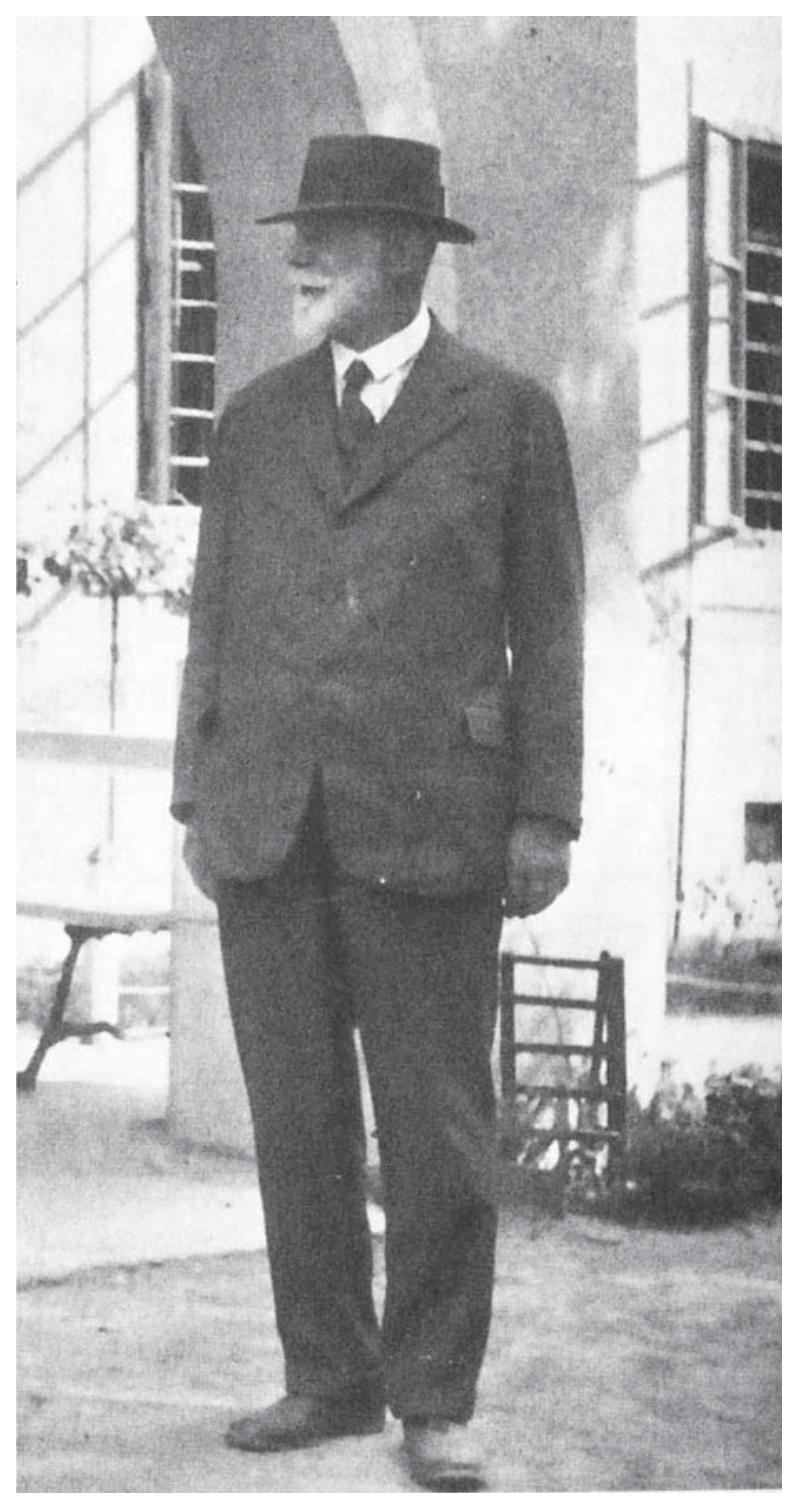

Foto 5. Miroslav Steinhausz, (1872. - 1966.) (arhiv autora)

Foto 5 Miroslav Steinhausz, (1872. - 1966.) (author's archive) 


\section{LITERATURA}

1. Čačić M. (1998.): Državna ergela lipicanaca u Đakovu. Diplomski rad. Agronomski fakultet Sveučilišta u Zagrebu.

2. Čačić M. (2003.): Fenotipske i genetske odlike lipicanaca u zemaljskom uzgoju Republike Hrvatske. Magistarski rad. Agronomski fakultet Sveučilišta u Zagrebu.

3. Čačić M. (2011): Genetska analiza lipicanaca u Hrvatskoj. Doktorska disertacija. Agronomski fakultet Sveučilišta u Zagrebu.

4. Čačić M. (2011): Povijest Državne ergele Stančić 1919. - 1938. Monografija. Zagreb

5. Ilančić, D. (1978.): Opskrba rasplodnim pastusima te osnivanje i djelovanje pastuharnice za Hrvatsku i Slavoniju. Stočarstvo, 32 (11-12), 405 - 419.

6. Petrović, M. (1929.): Studij rasta kod lipicanske ždrebadi na Državnoj ergeli Stančić u prvoj godini života. Doktorska disertacija. Zavod za živinogojstvo Poljoprivrednog fakulteta Sveučilišta u Zagrebu.

7. Steinhausz M. (1924.): Lipicanac. Postanak i gojidbena izgradnja pasmine. Gospodarska knjižnica, Zagreb.

8. Steinhausz, M. (1926.): Pravilnik o držanju državnih pastuha u privatnoj njezi i pod zakupom. Uprava Državne ergele Stančić. Zaklada tiskare narodnih novina. Zagreb.

9. Steinhausz M. (1926.): Utakmica u daljnjem jahanju na $255 \mathrm{~km}$. Poljoprivredni glasnik, 15. listopada 1926. godine, str. 13-14.

10. Steinhausz, M. (1928.): Konjogojstvo na području uprave Državne ergele Stančić. Gospodarski list, broj 5. Preštampan separat. Štamparija Linotip. Zagreb.

11. Steinhausz M. (1943.): Linije pastuha i rodovi hrvatskog lipicanaca. Gospodarska knjižnica, Zagreb.

12. Steinhausz M. (1930.): Das „Turc-Main-Atty“ Blut in der Landespferdezucht von Ungarn, Rumänien und Südslawien. Zeitschr. f. Tierzüchtung u. Züchtungsbiologyie, Bd. 18, Berlin.

13. Steinhausz M. (1931.): Rodovnica i rodoslovlje - Sastavljanje i upotreba kod izbora i parenja rasplodnjaka. Poljoprivredna knjižnica, Zagreb.

14. Steinhausz M. (1930.): Zemaljski uzgoj konja s posebnim osvrtom na Vojvodinu. Gospodarski list, br. 11 i 12, Zagreb.

15. Steinhausz M. (1933.): Temelji uzgoja konja. Napredak sela. Zagreb.

16. Steinhausz M. (1934.): Uzgoj konja u Međimurju. Poljoprivredna knjižnica, Zagreb. 
17. Steinhausz M. (1935.): Uzgoj konja u Savskoj banovini. Ibidem, Zagreb.

18. Steinhausz M. (1935.): Jugoslavenski nonius. Ibidem, Zagreb.

19. Steinhausz M. (1939.): Uzgoj konja. Ibidem, Zagreb.

* Steinhausz, M.: Osobni materijali, rukopisi i dnevnici rada u Državnoj ergeli Stančić.

* Anon. (1908.) - Ugovor i uputa o preuzimanju zemaljskih pastuha u privatnu njegu. Kraljevska zemaljska tiskara. Zagreb.

\section{Adresa autora - Author addresses}

Dr. sc. Mato Čačić

e-mail: mcacic@hpa.hr

Hrvatska poljoprivredna agencija

Ilica 101, 10000 Zagreb

\section{Primljeno-received:}

20.12.2017. 